Ivo Goldstein

\title{
The Tito-Stalin Split of 1948 as a Personal Conflict
}

The conflict in 1948 was quite complex and stratified - it was ideological and political, with obvious economic roots and consequences. Nevertheless, it was also personal because it was a conflict between two charismatic personalities - Josip Broz Tito and Ioseb Besarionis dze Jughashvili - Stalin.

In modern historiography, different terms are used for the events of 1948: the split between Yugoslavia and the Eastern Bloc, or the Yugoslav-Soviet split, but also the Tito-Stalin split, for quite obvious reasons.

I am not an adherent of the 19 century historical concept of Leopold Ranke, who views the development of the main historical processes as a struggle between key historical persons, as he shows in his emblematic work Die römischen Päpste, ibre Kirche und ibr Staat im sechzehnten und siebzehnten Jahrhundert (The Popes of Rome, Their Church and State in the Sixteenth and Seventeenth Centuries), in which he offers colorful portrayals of Pope Paul IV, Ignatius of Loyola and Pope Pius V. Despite all my reluctance, it has to be said that the roles of Tito and Stalin, the key personalities in the events of 1948, were essential. One can compare these events with those 20 years later - can anybody say that the invasion of Czechoslovakia and the crushing of the Prague Spring was a consequence of a Brezhnev-Dubcek conflict?

The conflict of 1948 was very much personalized. Latinka Perović observes that "at a juridical and at a symbolic level, Tito was Yugoslavia and Yugoslavia was Tito." ${ }^{\prime 1}$ Needless to say, Stalin was the Soviet Union and the Soviet Union was Stalin.

In the beginning, it was like a love story. Tito saw Stalin for the first time in 1935 during the Seventh Congress of the Comintern in Moscow. Tito was among the delegates, Stalin was sitting at the podium, raised up from everybody, like a god. At that time, Stalin was the subject of a pervasive personality cult within the international Marxist-Leninist movement; Tito was one of the believers.

1 Perović, Josip Broz Tito, p. 23. 
However, Stalin loved Tito, despite his suspect character. In certain elements, Tito's biography was similar to Stalin's: born to a poor family and repeatedly arrested, he entered the party hierarchy out of the blue, i.e. owing to his own merits. At the funeral of Mikhail Kalinin in 1946, Stalin invited Tito to the central podium and placed him at his side, the only foreign leader to be so honored. That would not have happened if Stalin had not had certain sympathy for Tito.

But soon after the war, it turned out that the Tito-Stalin relationship would be yet another story about love and hatred, like so many others. Keeping in line with that perspective, Koča Popović, one of Tito's closest collaborators, claimed that "that conflict was absolutely unavoidable." Openly criticizing Stalin after his death, Nikita Khrushchev concluded that in general Stalin gradually developed a "hatred toward Tito."

Already in 1945, the Yugoslav communist movement enjoyed greater independence than its counterparts in Eastern Europe because it had largely fought its own way into power. Tito had returned to Yugoslavia in 1938 as a Soviet communist agent or Soviet pawn, but his wartime victories had helped him outgrow that early role and develop into an extremely confident leader who would not allow the USSR and Stalin to dictate to him. His ambitions also grew. ${ }^{3}$

One of the outstanding features of Tito's character was his personal courage. $\mathrm{He}$ demonstrated it in 1928, during his trial called Bombaški proces. He was tried in November 1928 for his illegal communist activities, which included allegations that the bombs that had been found at his address in Zagreb had been planted by the police. He acknowledged that he was a member of the Communist Party of Yugoslavia (CPY), fully aware that this would bring him longer imprisonment. Indeed, he was sentenced to five years' imprisonment. ${ }^{4}$

When war came to Yugoslavia in 1941, Tito bravely called for an uprising against the invading Germans and Italians and from almost nothing created a movement of resistance fighters that would come to be known as the Partisans.

He displayed the same courage in facing down Josef Stalin, which led to the break between the Soviet Union and Yugoslavia in 1948. By trusting his own judgment once again, he was able to gather enough partisan veterans and other men ready to support him against this direct confrontation with the Soviet Union and even to resort to an armed struggle if necessary.

After the war, Tito was seen as the second leader in the Eastern Bloc after Stalin. According to some testimonies, Tito's popularity among party leaders and the public in Eastern European countries in 1946-1947 was high, perhaps even equal to Stalin's. A

2 Nenadović, Razgovori s Kočom, p. 130; Đilas, Vlast i pobuna, p. 131; Khrushchev, Memoirs of Nikita Khrushchev, p. 509.

3 I. Goldstein - S. Goldstein, Tito, p. 169.

4 Sobolevski, Bombaški proces Josipu Brozu; Goldstein - Goldstein, Tito, pp. 61-67. 
great expert on the history of that time François Feytö claims that "in the autumn of 1947 Yugoslavia was at the height of its prestige within the Eastern Bloc: it was enjoying a honeymoon with the international communist movement."This was perhaps one of the reasons for Stalin's actions in $1948 . .^{5}$

The state that Tito led had become his personal plaything: he had tried to achieve domination over Albania, he planned to make himself the head of a Balkan federation that would include Bulgaria, he was helping Greek communists in the Greek Civil War, he was firmly defending Yugoslav territorial claims against Italy and he complained to the Soviet authorities when they imposed unequal economic relations on Yugoslavia, practically bordering on exploitation.

Tito himself had already started creating his own personality cult in late 1942, a few days after he revealed his true identity. ${ }^{6}$

One of the reasons why Tito was so popular in Yugoslavia lies in the structure of the leadership: by the end of the 1930s, Tito had chosen his closest collaborators, who were all almost 20 years younger than he was - Aleksandar Ranković (1909), Edvard Kardelj (1910), and Milovan Đilas (1911). He created a relationship, even a friendship, with all three of them. They called him Stari - the Old Man. However, with Andrija Hebrang (1899), with whom he had a long friendship dating back to the late 1920s, he had a different kind of relationship, and Hebrang could call him Joža (which is ahypocorism of Josip).

Nevertheless, Hebrang became a personal rival, was arrested, and he allegedly committed suicide in prison. It cannot be said that this happened because of their rivalry since the origins of the clash between Tito and Hebrang were much deeper. At the same time, one cannot deny that this personal rivalry played a role in that affair. ${ }^{7}$

After taking power in virtually all of Yugoslavia in 1944-45, Tito created an archetypal Bolshevik system, part of whose structure was a personality cult of the leader. Tito drew his greatest support from Bosnia and Herzegovina, Montenegro and from a large part of Croatia, primarily by proposing the creation of a state that would be free of foreign conquerors, free from the Ustasha terror and without Greater Serbian hegemony. At the same time, he took advantage of the four years of war to solidify his personal popularity, which would ensure his position as the leader of the country after the end of the war.

In any case, even the Soviets themselves recognized his merits and were even raising his self-confidence - in 1944 the writer Ilja Erenburg wrote in the Moscow press that "Yugoslavia is not a detail and not an episode in World War II" and that "the entire

5 Feytö, Histoire des démocraties, pp. 198-199; Dedijer, Josip Broz Tito - prilozi za biografju, p. 486; Berić, Zbogom XX. stoljeće, p. 55; Đilas, Vlast i pobuna, pp. 174-175; Terzić, Titova vještina vladanja, p. 223; see also: Sovilj, Tito i čehoslovačka javnost 1945-1948., pp. 489-497.

6 Goldstein - Goldstein, Tito, pp. 479-497.

7 Ibid., pp. 471-473; Ivanković - Vonta, Hebrang. 
world is talking about the Yugoslav national liberation army, and the name of Marshal Tito is known on all five continents of the world."

Nevertheless, as the months after the war passed, Stalin became more and more suspicious of Tito - because of his ambition of becoming a regional leader, this former guerilla chief could become a problem and disrupt his entire strategy. Stalin did not need local skirmishes, let alone local victories - in the postwar period, a sphere of influence in Yugoslavia and its surrounding region played a secondary role. Stalin was primarily interested in the center of Europe - Germany. Another reason why Stalin wanted to discipline Tito was that he was afraid that the ambitious Yugoslav leader might become involved in a serious conflict with the West, especially with the United States, which had the atomic bomb, while the Soviet Union at that time did not. "There was some internal logic to the Soviet attitude. How much the leadership of some country consistently carries out proletarian internationalism is not measured by the struggle between fascism and national socialism, as the Yugoslav leadership and Tito emphasized, but by a positive attitude toward the USSR and the unquestioned defense of the first country of socialism," which, of course, included absolute obedience to Stalin. ${ }^{9}$

Tito's disobedience was both a danger and a challenge because it could incite disobedience in other countries and parties and their leaders. ${ }^{10}$

In addition, the devotion of Tito and his collaborators to bolshevism, claims Tony Judt, always seemed to Stalin as "too enthusiastic. Stalin was always less interested in spreading bolshevism than in spreading his power." ${ }^{\text {11 }}$

Close relations between the two communist movements and the two leaders began to shake even during the war because Tito sometimes acted independently, irrespective of Moscow's ambition to dominate. Koča Popović observes that "during the war, Tito had become accustomed to independence so that, already by the nature of his position, charisma, and the authority connected to his personality, he could no longer even think of returning to a position subordinate to Stalin". ${ }^{12}$

Thus, in September 1944, Tito had obtained for the Yugoslavs an agreement with Stalin that none of the other Eastern European countries had achieved - sufficient reason for Stalin to feel that his prestige was being threatened. ${ }^{13}$

As the war was coming to an end, Tito was increasingly emphasizing the strength and independence of the movement that he was leading and the importance of the state he had just created. In September 1944, he said that "we want to sit together with our allies at the table where the destiny of Europe, including our own country, will be

8 Dedijer, Novi prilozi, III: 200-201; Anikejev, Sovjetsko-jugoslavenski sukob, p. 463.

9 Jakšić, Smutna vremena, p. 74.

10 Đilas, Susreti sa Staljinom, p. 82; Judt, Postwar, p. 145.

11 Judt, Postwar, p. 140.

12 Nenadović, Razgovori s Kočom, p. 104.

13 In detail, Goldstein - Goldstein, Tito, pp. 443-478. 
decided."In late October, when he learned that Churchill and Stalin had negotiated in Moscow about spheres of influence in Yugoslavia, he stated that Yugoslavia was not and could not be a "bargaining chip", indicating that he would not submit to any Soviet dictates. He added that "today's Yugoslavia cannot be compared with that of 1919. Today, there is a new Yugoslavia." The Soviet government quickly responded that it perceived "Comrade Tito's speech as a hostile act against the USSR." By making this statement, Tito had hit at the very essence of Soviet hegemony, which became the main point of the indictment against him in $1948 .{ }^{14}$

A new, significant disagreement occurred in late 1944, when news reached Tito that Soviet officers were massively raping Yugoslav women and girls, which Milovan Đilas loudly condemned, and which Tito abhorred and probably protested, but considerably more quietly. ${ }^{15}$

Toward the end of the war, Tito increasingly showed that he wanted to position Yugoslavia as a regional power with himself as its leader. Already in May 1945, he deviated from the dogma about the two phases of the revolution, imposed by Bolshevik propaganda, and claimed that in the construction of socialism "we are going new ways, another way, imposed on us by the situation of this great liberation war." He concluded by saying that "we will glide inconspicuously into communism, and we will not observe the two phases of the liberation war because the stages of the bourgeois-democratic and proletarian revolution are not well-formed." 16

Moscow judged that deviation from strictly established revolutionary canons as just another Yugoslav blasphemy. Furthermore, there was one other thing that Moscow did not like - the Yugoslav five-year development plan. Adopted in 1947, it stressed the need for the development of heavy industry, while Moscow pushed for the development of agriculture, the construction of energy plants and the exploitation of mineral resources (and Žujović and Hebrang supported Moscow's ideas). In fact, Moscow saw Yugoslavia as the granary of South East Europe, but Tito did not agree. In a speech to the parliament during the adoption of the plan, Tito mentioned the USSR only once, stating that "in a socialist economy, such as that in the USSR, a crisis is not possible"- and nothing more. Not a word about Stalin, although this was a good opportunity to mention the genius creator of the first five-year-plan in the world. Observers also noted that Tito emphasized the need for the economic and political independence of Yugoslavia. ${ }^{17}$

14 Tito, Sabrana djela, 23:113; 24:135; see also: Đilas, Vlast i pobuna, pp. 137-138; Dedijer, Novi prilozi II: 918919; Dedijer, Novi prilozi III: 103-104, 883; Strčić, Tito: Naša Istra, p. 36; Feytö, Histoire des démocraties, p. 72; in detail, Mićunović, Moskorske godine.

15 Tito, Sabrana djela, 24:95; Dedijer, Josip Broz Tito, p. 442; Dedijer, Novi prilozi II:196-197, 640-641; Deutscher, Staljin, politička biografja, p. 509; Simić - Despot, Tito, strogo porjerljivo, pp. 130-133; Popović, Jugoslovensko-sovjetski odnosi, p. 167; Pirjevec, Tito i drugovi, pp. 190-191; Nikoliš, Korijen, stablo, pavetina, p. 637; Mandić, $S$ Titom, pp. 74-76.

16 Dedijer, Novi prilozi III:136; Vodušek Starič, Kako su komunisti, p. 235.

17 Vjesnik, 1. V. 1947; Feytö, Histoire des démocraties, p. 168. 
During these years, Tito was reluctant to congratulate the Soviet leader on his birthdays and other important anniversaries, unlike many other Eastern European leaders. He acknowledged the concrete achievements of Stalin and the USSR, but he did not indulge in emotions. Furthermore, Tito felt that there were many problems and issues about which it was not necessary to consult Moscow, and for which Stalin thought that such consultations were "necessary". Stalin believed that the CPY should be "a role model for other parties," but that meant "the CPY and its leadership would enjoy his special confidence while implementing Soviet policies."

This did not mean that Tito received a "green light" for independent action from Stalin..$^{18}$ At that time, Tito was giving free reign to his charisma, and he was establishing a cult of his personality in Yugoslav society. The Soviets could not have missed the fact that in the second half of 1946 an issue of the military magazine Narodna armija published 23 photographs of Tito and only five of Stalin. ${ }^{19}$

Tito also refused to allow the Soviets to create a parallel intelligence network. ${ }^{20} \mathrm{In}$ June 1947, the Soviet authorities apparently sought permission from Belgrade for the Red Army to establish naval bases in Pula, Šibenik and Boka Kotorska. They tried again in early 1948, but Tito refused both times. ${ }^{21}$

Thirty years later, in 1978, Kardelj recalled how Stalin "tolerated Tito, in spite of the hatred that was boiling in him. I think that he was somehow afraid of us because Yugoslavia was genuinely independent and we were ready to react to his demands." Kardelj also claimed that "Within the entire socialist movement, Stalin hated Tito the most, and therefore sought any opportunity to subvert him."22

Stalin's biographer, Simon Sebag Montefiore, claims that "the federation of Bulgaria and Yugoslavia, which Tito wanted to create without Stalin's permission," was the moment when Stalin concluded that "enough was enough." At a meeting with senior Yugoslav officials (Kardelj, Đilas, Ranković), he said, "when I say no, that means no!" He suggested that "Yugoslavia should swallow up Albania, and with fingers and mouth he imitated swallowing," but the Yugoslav trio was unimpressed. Speaking to François Feytö in 1983, Đilas said that at that time they were unaware of the ultimate goal of Stalin's manipulation, namely, "the perfidious Georgian wanted to see how far Tito's ambitions went." ${ }^{3}$

Both Tito and Stalin were making decisions in these key moments, but "there was a difference in the way that they were reaching those decisions. Stalin was everything,

18 Anikejev, Sorjetsko-jugoslavenski sukob, p. 462.

19 Dimitrijević, Jugoslovenska armija, p. 803.

20 Đilas, Vlast i pobuna, pp. 118, 131, 133-134.

21 Pirjevec, Tito i drugovi, p. 243.

22 Dedijer, Novi prilozi IIII:127.

23 Dedijer, Josip Broz Tito, p. 470; Đilas, Susreti sa Staljinom, p. 82; Montefiore, Staljin, p. 566; Feytö, Mémoires, pp. 303-305. 
his word was the first and the last. Tito did it in a wiser way. He listened to the opinions of the people around him, sometimes even abandoning his ideas and suggestions and accepting the majority opinion within the Yugoslav leadership (...) The personalities of Tito and Stalin were quite an important factor in the conflict. Their social psychology was created in the regions in which they grew up." "Resistance to Stalin was," Vladimir Dedijer clarified, "more a spontaneous response to the aggressive pressures in defense of independence and freedom," than an awareness of Tito and his associates of historical consequences of resistance to the USSR. ${ }^{24}$

Stalin had abundant experience in executing his rivals, and he was carefully preparing to deliver the final blow to the heretic, which Tito now was in his eyes. Tito was warned by several people that Stalin wanted to remove him, including the General Secretary of the Communist Party of Romania, Gheorghe Gheorghiu-Dej, and Josip Kopinič, his friend and Soviet intelligence officer, who was then on a mission in Turkey.

Yet another warning - this time announced in public - came in mid-February. The Vienna correspondent of the Paris newspaper Le Figaro wrote that Tito's portraits had been removed from all Bucharest shop windows, where they used to be displayed together with portraits of other prominent communist figures. The well-informed correspondent speculated that "Tito has lost the trust of Moscow" and concluded that these are "at the moment unconfirmed rumors, but deserve to be noted." 25

In his actions Stalin applied "the methods of an inquisition" and, more importantly, "all of these methods have been improved and used in his own country in the struggle against the Old Bolsheviks and against an enormous number of his own population."26

Stalin thought that he could apply the same methods in Yugoslavia. As Jean-Marie Soutou, a former high-ranking French diplomat in Moscow explained, "If the branch does not bear fruit, it should be cut off." In Soutou's view, there were different solutions for a compromise, but for Stalin there was only one alternative, "I'm breaking him, or I am capitulating." 27

So, in the case of Tito and Yugoslavia, the strong man of the Kremlin did not show inventiveness and it came back to haunt him. Meanwhile, in February 1948, he pressured Czechoslovakia and the Communists took power in that country. These events further convinced Stalin of his own omnipotence.

The fact that Tito was crossing the red line in many respects forced Stalin to react. On 18 March, General Barskov, serving in the Soviet Embassy in Belgrade, informed Tito personally that the Soviet government was withdrawing its military advisers from

24 Dedijer, Novi prilozi III:30, 191.

25 Dedijer, Josip Broz Tito, p. 505; Dedijer, Novi prilozi III:257, 258; Pavlowitch, Tito, Yugoslavia's Great Dictator, p. 57; Đilas, Vlast i pobuna, p. 208; Jakovina, Američki komunistički saveznik, p. 239; Le Figaro, 12. II. 1948.

26 Dedijer, Novi prilozi III:32.

27 Soutou, Un diplomate engage, p. 64. 
Yugoslavia. The following day, the Soviet chargé d'affaires Armjaninov announced that civilian advisers would also be recalled. The alleged reason was that it was impossible for them to remain in an atmosphere of hostility. Incidentally, the most important work of these advisers was recruiting for the Soviet secret services. According to Tito's later testimony, that was the moment when he felt there was a deep "distrust or misunderstanding" and that "it was like the story about the wolf that accuses the lamb of polluting the water in a brook, although he is drinking upstream from the lamb." According to Stalin's successor as General Secretary of the Communist Party, Nikita Khrushchev, it was the beginning of an "artificial influx of conflict between the USSR and Yugoslavia." 28

At a session of the extended Politburo on 1 March, Tito spoke very openly about some elements of the conflict. He pointed out that the proposed Danube navigation agreement was "for us shameful" and that the air transport agreement was "unbalanced." He added that the Soviets said, "Why do you need a strong army? We are here," and that the Soviets "are exerting economic pressure on us. We must endure this pressure." He then concluded, "The independence of our country is at stake." ${ }^{29}$ Then, in an unexpected and, according to Đilas, pathetic manner, Tito offered his resignation (it was the first and the last time he would do this, if we do not count the dramatic meeting of CC in Drenovi in December 1941), but he added, "if the Russians continue with such a policy toward us." Đilas did not think that Tito was serious, but that "he did it to test the attitude of the people present, and whether they would find anyone who would accept the resignation." "Everyone was unanimously against such an idea, and only Tito's long-term, close associate Sreten Žujović was conspicuously keeping his mouth shut." ${ }^{\prime 30}$

Moscow carefully continued to increase its pressure. Letters from Moscow were signed by the Central Committee. Tito answered them from Belgrade and wrote to Stalin and to Molotov, who was the Minister of Foreign Affairs. The difference is obvious. Moscow wanted to keep the conflict within the Party, while Tito was trying to expand it to the relations between the two countries. Đilas described how "during that time Pavel Judin, the editor-in-chief of the Cominform magazine and the Soviet representative in the Cominform, visited Tito. He asked Tito to write an article for his magazine- as if nothing was happening between the two leaders. Tito agreed, but no one interpreted Judin's visit to Tito as related only to that article. Both we and the Soviet officials were aware that nothing happens by chance (...) Judin's visit to Tito was part of their planned tactics. At first, Tito should not be provoked, the aim was to separate him from the rest of the leadership, to give him the prospect of personal salvation." Nevertheless, things did not develop the way Moscow had planned. ${ }^{31}$

28 Tito, Autobiografska kazivanja, II:25; Tajni referat N. S. Hrǔ̌čova, p. 70; Dedijer, Josip Broz Tito, p. 443; Špadijer, Vladimir Poporic Španac, pp. 184-185; Feytö, Histoire des démocraties, p. 226.

29 Dedijer, Dokumenti 1948, knj. 1:194; Dedijer, Josip Broz Tito, pp. 507-509; Dedijer, Novi prilozi III: 304.

30 Đilas, Vlast i pobuna, p. 211; Đilas, Druženje s Titom, pp. 130-131.

31 Đilas, Vlast i pobuna, p. 215; Feytö, Histoire des démocraties, p. 227. 
Though Tito wrote to Molotov, warning him in a very friendly way that the withdrawal of experts was damaging and unfounded ("our wish would be that the USSR government inform us frankly what this is about ... such a course of action is detrimental to both countries. Sooner or later, we will have to remove all the obstacles that can harm friendly relations."). Nevertheless, new, greater tensions occurred very soon. On 27 March, the Soviet Central Committee, but in fact Stalin, sent to the Yugoslav Central Committee a letter stating that there was "a lack of democracy in the country," that the Yugoslav authorities were trying to "dethrone the Soviet system," and that they were accusing the USSR of "great state chauvinism." The Yugoslav Central Committee was accused of revisionism. It was also claimed that British spies were working in the Yugoslav Ministry of Foreign Affairs. Finally, Tito was accused of the most grievous of sins - Trotskyism ("we consider Trotsky's political career to be sufficiently instructive"). There was no doubt that "Stalin had decided to destroy Tito."

A plenary session of the Yugoslav Central Committee convened on 12 and 13 April in the library of the Old Court, where meetings were never held, so there was little possibility that the Soviets could listen in on it. Tito came to the meeting "aware of its fateful meaning" (François Feytö called it a "fateful battle"). Afterwards, Tito told Dedijer that "life taught him that in such critical moments the most dangerous thing is to be without an attitude, which means - to hesitate. In such a situation one must always react boldly and decisively." Tito chaired the session and made a one-hour introductory speech. He stressed that "this is not a theoretical discussion, it is not about the mistakes of the CPY, about our alleged ideological aberration. We should not let ourselves be pushed into a discussion about it (...) this is a letter of tremendous slander. Incorrect accusations. Please keep the discussion cool-headed."

Sreten Žujović had a different opinion. Đilas, who was sitting next to him understood that "Žujović was shaking for himself. Betrayal! The betrayal of the people, the state, and the Communist Party!' Tito also understood Žujović's condition, so he turned to him and said: "You, Black (Black was Žujović's nickname), have exercised the right to love the USSR more than I do (...) Our Party is pure as the sun”. Then he paused, stood up and said: "Comrades, our revolution does not eat its children. The children of this revolution are honest." Tito was "outraged sincerely, deeply. This was inspired by his personal qualities- he perceived political processes as personal problems, and vice versa -he treated personal situations and moods as problems of the Party and the state," Đilas concluded. ${ }^{32}$

After a "bitter and combative" discussion, "a discussion full of anger," in which $\check{Z} u$ jović was attacked by Tito and by many others, it was decided that the Yugoslav Central Committee would respond to the charges from Moscow. In a 33-page letter, the Central

32 Đilas, Vlast i pobuna, p. 219; Dedijer, Josip Broz Tito, pp. 517-520; Feytö, Histoire des démocraties, pp. 232-234; Pirjevec, Tito i drugovi, p. 260. 
Committee and Tito expressed their dissatisfaction ("terrible astonishment") with the opinions expressed in the letter of 27 March and the manner in which it was done. In addition, the letter argued that there was essentially a difference in understanding what the relationships between socialist countries should be. It primarily urged mutual understanding and asked that local circumstances and traditions should not be sacrificed, but respected. Tito was prepared for only one concession: the replacement of Vladimir Velebit as assistant foreign minister followed by a detailed investigation of the case.

At that moment, Tito and his associates were trying to affirm the view that relations between socialist countries and parties should be based on equality. The senior state and party hierarchy (except Andrija Hebrang and Žujović), as well as central committees at the republic level, supported the letter. Žujović was expelled from the Central Committee, and later arrested along with Hebrang. Thus, the Yugoslav leadership supported and remained unified behind Tito. Stalin had lost the first round of the conflict. News of the removal of Hebrang and Žujović because of "hostile and anti-national work" was published two months later, when the "Resolution of the Cominform" was published. ${ }^{33}$

In a letter sent to Yugoslavia in early May, Stalin and Molotov assessed the Yugoslav Central Committee's response as "an intensification of the conflict." They viewed the letter from Belgrade almost as an "accusation," underlining the "anti-Soviet position of Comrade Tito" and speaking of "defamatory propaganda from the leaders of the CPY."Tito (along with Kardelj) was identified as the main cause for the disorder in the ranks of the Yugoslav Communist Party. In the meantime, silent changes were hardly noticeable, but they were significant: during the 1 May parade in Belgrade, there were more pictures of Tito than of Stalin, and the only communist leader who congratulated Tito on his birthday (25 May) was Georgi Dimitrov.

A meeting of the Cominform was convened from 20 to 22 June in Bucharest. Tito and his associates did not attend (the Yugoslav ambassador in Moscow, Vladimir Popović, thought that their attendance would be "suicide"). Instead, they sent a letter to the participants of the meeting in which they stressed that the issue of disagreements had been "incorrectly" presented and that discussions in Bucharest would only lead to a deterioration of the situation. "We feel so unequal in this matter that we cannot accept trying to resolve it at the meeting in Bucharest," they claimed. They knew that their position would be unanimously condemned, and that they, most probably, would not return from Bucharest. Tito later said that he "knew what his trip to Bucharest would mean. Well, I've already paid off my life a long time ago. I could go and die there, if that would be of any use." ${ }^{34}$ But, of course, it was not.

33 Riječki list, 22. VI. 1948; Dedijer, Josip Broz Tito, p. 525; Šuvar, Vladimir Velebit - svjedok historije, pp. 163-164; Pirjevec, Tito i drugovi, pp. 257-258; Đilas, Vlast i pobuna, pp. 139-140, 218-230.

34 Broz, Autobiografska kazivanja II:23; Đilas, Vlast i pobuna, pp. 224, 226; Dedijer, Novi prilozi II:1232; Špadijer, Vladimir Popovic Španac, p. 189. 
During the discussion of "the situation in the CPY" in Bucharest, the Soviets wanted to turn the Cominform into a court. Obviously, if Tito and his associates had been there, the meeting would have been transformed into something like the Stalinist Moscow trials, where the accused would express self-criticism, thus signing their death sentence. Andrey Ž danov claimed that Moscow "possesses information that Tito is an imperialist spy," which leaves no doubt as to what Tito's fate would have been. ${ }^{35}$

The text of the "Resolution of the Cominform," which was signed by all participants of the meeting in Bucharest, summarized and reinforced the previous accusations and criticisms of the Yugoslav leadership. Initiatives were welcomed to "unmask the improper policies of the Yugoslav Central Committee and, above all, the improper policies of Comrades Tito, Kardelj, Đilas and Ranković."

Over time, Tito and his associates understood that if the Yugoslav public knew what was happening, it would support them. Therefore, when the text of the "Resolution of the Cominform" came to Yugoslavia, they decided to publish a response to it, which they called a "Declaration." At first, Tito did not want to publish the "Resolution of the Cominform", but only the Declaration. However, he soon accepted the majority opinion of the Politburo and agreed to publish the resolution as well. ${ }^{36}$

The "Resolution of the Cominform" was published in newspapers on 30 June and broadcast on the radio. It was a great shock to the Yugoslav public, but an even greater one for Stalin and his associates. That same day, Tito and several associates (Bakarić, Koča Popović, Svetozar Vukmanović-Tempo and others) visited the construction site of New Belgrade. They stayed for two hours. Tito talked with the supervisors and workers. He was interested in "how the work and their lives [were] progressing." He visited "almost all of the housing barracks." The workers "cheered Tito, shouting Tito- Party." Life in Belgrade was quite normal. International telegraph and telephone traffic was not disrupted, trains ran on schedule, and no special military or police measures were discernible. Tito's visit to the construction site appeared at the top of the front page of all of the newspapers, suggesting to the Yugoslav public that nothing was happening which would disturb Tito's daily commitments and that he had not lost the support of the people.

The "Resolution of the Cominform" predicted that "healthy forces" would soon take the initiative and overthrow Tito and his associates. Speaking at the 20th Congress of the CP USSR in 1956, Nikita Khrushchev stated that at this time Stalin boasted that all he had to do was "lift his little finger and Tito would no longer be there. He would fall." Stalin thought that Tito and his associates would not be able to withstand the pressure and that they would resign. François Feytö warned that Moscow should not be

35 Feytö, Histoire des démocraties, p. 194; Montefiore, Staljin, p. 568.

36 Đilas, Vlast i pobuna, pp. 236-237. 
underestimated. "Stalin and his associates could believe in such a result because Moscow had secured significant support within the Yugoslav military, police, party circles." On the basis of these estimates, Moscow calculated that there would be a split in the Yugoslav Communist Party and Yugoslav society. Only a little help would be needed from Moscow for "healthy forces" to prevail, such as when they showed that they would protect Hebrang and Žujović. Soviet intelligence from Belgrade probably overestimated the strength of this "serious support," which clearly began to weaken when Tito and his associates launched their counter-offensive. In addition, Stalin was relying on his authority within the international communist movement and the unconditional support of the Cominform member states. However, the Kremlin strongman was deluding himself when he demanded the degrading humiliation of the victors of the war in Yugoslavia. ${ }^{37}$

Tito rightly estimated that he had support among the Yugoslavs (compared to other Eastern bloc leaders, Tito's personal popularity in 1948 was incomparably greater). Tito could also count on the support of the party elite. In other words, he had the strength to oppose Stalin, although there were many people in Yugoslavia who, because of their radicalism and indoctrination, admired Stalin as the "guardian of the only truth." Tito's reputation as a victor in wartime and a self-proclaimed post-war leader could not be tarnished by insinuations from Moscow, which recklessly and crudely denied some of the most important CPY achievements in the war. For example, a letter in May 1948 claimed that in the summer of 1944, "the Yugoslav National Liberation Movement survived a grave crisis," and that "the Soviet army came to the aid of the Yugoslav people, smashed the German occupiers, liberated Belgrade and thus created the conditions necessary for the Yugoslav Communist Party to come to power." Moscow also claimed that "Tito and Kardelj did not take this into account," and therefore "they should be more decent and humble." It concluded that "Yugoslav leaders were getting on everybody's nerves with their exuberant boasting" about their successes during the war. Of course, in the summer of 1944 the Yugoslav National Liberation Movement was not in crisis. In fact, they had started the liberation of Dalmatia and the southern parts of the country and had penetrated into Serbia, and the Soviets did not liberate Belgrade on their own. ${ }^{38}$

Last but not least, 3,000 survivors of the famous Partisan battles at Neretva and Sutjeska knew that the Soviets were lying and they were prepared to fight to the death for Tito.

Despite all of this, Tito and Yugoslavia continued to adore Stalin until the last moment and even after it. Stalin's biographer Montefiore precisely concludes, "The departure of Yugoslavia from the Eastern bloc was an unnecessary consequence of Stalin's

37 Tajni referat N. S. Hrušcova, pp. 69-70; Anikejev, Sorjetsko-jugoslavenski sukob, pp. 463-464.

38 Koren, Prošlost na koju su sjećanja svake godine sve življa, p. 41; Petranović - Zečević, Jugoslavija 1918-1954, p.759; Popović, Za pravilnu ocenu. 
stubbornness." ${ }^{39}$ One month after the "Resolution of the Cominform," in the prevailing tense and uncertain atmosphere of the Fifth Congress of the CPY, Tito and the Yugoslav communists were still saluting Stalin. Tito concluded his report with the words, "Long live CPY! Long live the USSR with the genius Stalin as its leader!" The delegates applauded and chanted "Stalin - Tito!" In Yugoslavia, Stalin's popularity was much weaker than Tito's. There was certain support for the Resolution of the Cominform, but much less than Stalin and his associates had expected and hoped for.

Therefore the deconstruction of Stalin's personal cult soon started in Yugoslavia. ${ }^{40}$ For example, the original version of the well-known song "With Marshall Tito, bravest hero" by distinguished Croatian poet Vladimir Nazor (1876-1949) goes as follows:

With Tito and Stalin, our two bravest heroes,

We'll be even stronger than Hell!

We raise our heads bravely, and don't hang down gravely,

And clench our fists hard as well.

Soon, the poem was rewritten and it went as follows:

With great Marshall Tito, our land's bravest hero, We'll be even stronger than Hell!

We raise our heads bravely, and don't hang down gravely,

And clench our fists hard as well.

As for Stalin, he started a propaganda war: anti-Yugoslav and anti-Titoist propaganda systematically denigrated Tito and "Tito's clique" in the USSR and all its satellites. Cartoons portrayed Tito with a swastika, or with a skull, and with a face the resembled to Hermann Goering's. It was claimed that "Tito's group has fallen into the mud of bourgeois nationalism," that it was "the fascist Tito's clique," or "the criminal gang of Tito-Ranković."

In Hungary, propaganda was spread that Tito was an "American dog on a chain" just waiting for a sign from Washington to attack. In the USSR he was "a traitor, a provocateur, a spy." There was also a gloomy pronouncement that gallows would be made for him at Terazije Square in the center of Belgrade. In Moscow, a certain Antony Maljcev published the novel The Yugoslav Tragedy, in which Tito and his associates were shown as Gestapo agents and associates of Western spy networks. The book won the Stalin Prize.

39 Montefiore, Staljin, p. 494; Feytö, Histoire des démocraties, p. 231.

40 Goldstein - Goldstein, Tito, pp. 511-516. 
One American diplomat concluded at this time that because of the adverse Soviet propaganda "Tito no longer needs to be removed physically, his regime can survive as the living object of the hatred of all communists." ${ }^{41}$

Josip Broz Tito won that battle, becoming the only international leader who gained victories over both Hitler and Stalin.

\section{Sources and literature}

\section{Sources}

Le Figaro (Paris), 12. II. 1948.

Vjesnik (Zagreb), 1. V. 1947.

\section{Literature}

Anikejev, Alekseii, Sovjetsko-jugoslavenski sukob 1948. godine. Loša volja Staljina ili svestan izbor Josipa Broza Tita. Olga Manojlović Pintar (ed.), Tito - viđenja i tumačenja. Beograd: INIS, 2011.

Bekić, Darko, Jugoslavija u bladnom ratu. Zagreb: Rad, 1988.

Bela knjiga o agresivnim postupcima vlada SSSR, Poljske, Čehoslovačke, Mađarske, Rumunije, Bugarske i Albanije prema Jugoslaviji. Beograd, 1951.

Berić, Gojko, Zbogom XX. stoljeće - sjećanja Ive Vejvode. Zagreb: Profil, 2013.

Dedijer, Vladimir, Josip Broz Tito - prilozi za biografiju. Beograd: Kultura, 1953.

Dedijer, Vladimir, Izgubljena bitka J. V. Staljina. Sarajevo: Svjetlost, 1969.

Dedijer, Vladimir, Novi prilozi za biografiju Josipa Broza Tita III. Beograd: Rad, 1984.

Deutscher, Isaak, Staljin, politička biografija. Zagreb: Globus, 1977.

Dimitrijević, Bojan, Jugoslovenska armija - oslonac Titovog kulta ličnosti u prvim posleratnim godinama. Olga Manojlović Pintar (ed.), Tito - viđenja i tumačenja. Beograd: INIS, 2011.

Đilas, Milovan, Susreti sa Staljinom. London, 1986.

Đilas, Milovan, Vlast i pobuna. Zagreb: Novi liber, 2009.

Feytö, Francois, Histoire des démocraties populaires, t. I. Paris, 1992.

Goldstein, Ivo i Slavko Goldstein. Tito. Zagreb: Profil, 2015.

Grigorov, Dmitar, Antititovske/antijugoslovenske karikature u Bugarskoj (1948-1953). Slučaj „Stršljen“. Olga Manojlović Pintar (ed.), Tito - viđenja i tumačenja. Beograd: INIS, 2011.

Ivanković, Zvonko - Vonta, Hebrang. Zagreb: Asocijacija naučnih unija Jugoslavije, 1988.

Jakovina, Tvrtko, Američki komunistički saveznik (Hrvati, Titova Jugoslavija i SAD 1945-1955). Zagreb: Profil, 2003.

Jakšić, Božidar, Smutna vremena. Beograd: Mostart, 2014.

Judt, Tony, Postwar. A History of Europe since 1945. II. ed. London: Penguin, 2007.

Khrushchev, Sergei (ed.), Memoirs of Nikita Khrushchev. Vol. 3. Penn State University Press, 2007.

41 Pirjevec, Tito i drugovi, pp. 304, 309-310; Bela knjiga, p. 238; Grigorov, Antititovskelantijugoslovenske karikature, pp.731-737; Vojtěchovský, Z Prahy proti Titovil; Bekić, Jugoslavija u hladnom ratu, pp. 35, 38, 89, 90, 110, 116, 123; Dedijer, Izgubljena bitka, p. 229. 
Koren, Snježana, Prošlost na koju su sjećanja svake godine sve življa: Povijest NOB-a i KPJ u školskim programima i udžbenicima 1945.-1960. Iskra Iveljić, Stjepan Matković, Žarko Lazarević (eds.), Iz hrvatske povijesti 20. stoljeća - Iz hrvaške z godovine 20. stoletja. Ljubljana: Inštitut za novejšo zgodovino, 2012, pp. 37-55.

Mandić, Blažo, S Titom - četvrt veka u Kabinetu. Beograd: Dangraf, 2012.

Mićunović, Veljko, Moskovske godine 1956-1958. Zagreb: Novi Liber, 1976.

Montefiore, Sebag Simon, Staljin - Na dvoru crvenog cara. Zagreb: Profil, 2009.

Nenadović, Aleksandar, Razgovori s Kočm. Zagreb: Globus, 1989.

Nikoliš, Gojko, Korijen, stablo, pavetina. III. izd. Zagreb: SNL, 1981.

Pavlowitch, Stevan K., Tito, Yugoslavia's Great Dictator. Reassessment. London: Hurst, 1992.

Perović, Latinka, Josip Broz Tito: Različite istorijske perspektive. Olga Manojlović Pintar (ed.), Tito - viđenja i tumačenja. Beograd: INIS, 2011.

Petranović, Branko i Momčilo Zečević, Jugoslavija 1918-1954, zbirka dokumenata. Beograd: Rad, 1985.

Pirjevec, Jože, Tito i drugovi. Zagreb: Mozaik knjiga, 2012.

Popović, Koča, Za pravilnu ocenu oslobodilačkog rata naroda Jugoslavije. Beograd, 1949.

Popović, Nikola B., Jugoslovensko-sorjetski odnosi u drugom svetskom ratu (1941-1945). Beograd: Institut za savremenu istoriju, 1988.

Simić, Pero i Zvonimir Despot, Tito, strogo porjerljivo, arbivski dokumenti. Zagreb: Večernji list, 2010.

Sobolevski, Mihael, Bombaški proces Josipu Brozu. Zagreb: August Cesarec, 1977.

Soutou, Jean-Marie, Un diplomate engage. Paris, 2011.

Sovilj, Milan, Tito i čehoslovačka javnost 1945-1948. godine. Olga Manojlović Pintar (ed.), Tito - viđenja i tumačenja. Beograd: INIS, 2011.

Strčić, Petar, Tito: Naša Istra. Dometi. Izv. svezak, 1980.

Terzić, Milenko, Titova vještina vladanja. Maršal i maršalat 1943-1953. Podgorica: Pobjeda, 2005.

Tito, Josip Broz, Sabrana djela. Vols. 23-24. Beograd - Zagreb, 1977.

Vodušek Starič, Jasna, Kako su komunisti preuzeli vlast 1944.-1946. Zagreb: PIP Pavičić, 2006.

Vojtěchovský, Ondrej, Z Prahy proti Titovi! Jugoslávská prosovètská emigrace v Československu. Praha: Filozofická fakulta Univerzity Karlovy, 2012. 


\section{Summary \\ Ivo Goldstein \\ The Tito-Stalin Split of 1948 as a Personal Conflict}

The conflict of 1948 was quite complex and stratified - it was ideological, political, with obvious economical roots and consequences. It was at the same time personal, because it was the conflict of two charismatic personalities - Tito and Stalin. The Yugoslav communist movement enjoyed greater independence than others in Eastern Europe because it had largely fought its own way into power. Tito came to Yugoslavia in 1938 as a Soviet communist agent, but his war victories helped him outgrow that early role and he developed into an extremely self-confident leader who would not allow the USSR and Stalin to dictate to him. His ambitions also grew. He tried to achieve domination over Albania, he planned to make himself head of a Balkan federation that would include Bulgaria, and complained to the Soviet authorities when they imposed unequal economic relations bordering on exploitation on Yugoslavia. All this made Stalin and the other Soviet leaders regard him with suspicion, and they began to exert various kinds of pressure on the Yugoslav leadership. The author investigates various aspects of this conflict. Josip Broz Tito won that battle, becoming the only international leader who gained victory over Hitler and Stalin. 